\title{
Государственные внутренние займы Тувинской Народной Республики и СССР в Туве (1920-1940 гг.)
}

\author{
Марианна М.-Б. Харунова \\ Тувинский институт комплексного освоения природных ресурсов СО РАН, Российская Федерация, \\ Рамиль Ш. Харунов \\ Нацииональный музей им. Алдан-Маадыр Республики Тыва, Российская Федерации, \\ Руслана Н. Базыр \\ Национальный архив Республики Тыва, Российская Федерация
}

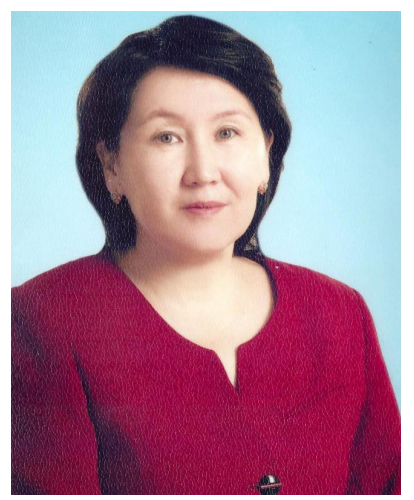

Для форсированного развития собственной промышленности и укрепления сельского хозяйства в Тувинской Народной Республике в 1930-1940-е годы пошли по советскому опыту мобилизации сбережений населения и средств предприятий в пользу страны путем распространения облигаций государственных внутренних займов. В статье на основе материалов Национального архива Республики Тыва, фондов Национального музея им. Алдан-Маадыр Тувы впервые показана история выпуска, размещения и обращения государственных внутренних займов СССР и ТНР на территории Тувы, а также вложения полученных заемных средств в развитие народного хозяйства республики.

Первые облигации государственных займов СССР 1927, 1928, 1929, 1930 г2. получили распространение среди командированных в Туву советских специалистов и местных жителей Русской Самоуправляющейся Трудовой Колонии. Далее Правительство ТНР широко использовало облигации госзаймов СССР. В 1942 и 1943 г2. ТНР выпустила облигации тувинских государственных займов. После вхождения в состав СССР был произведен обмен этих облигаций на облигации Третьего государственного военного займа СССР.

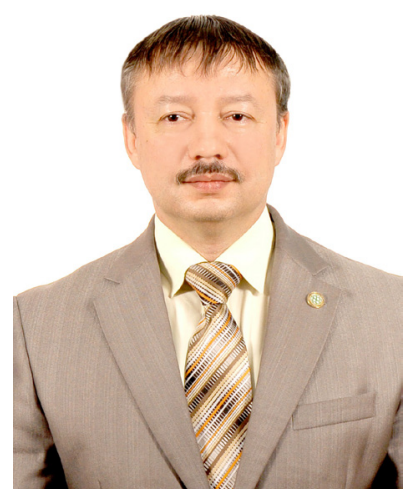

Показаны различные методы распространения облигаций госзаймов, например, плановые, с обязательными контрольными цзифрами, социиалистическими соревнованиями и обязательствами по подписке на облигации через трудовые коллективы, были и за наличный расчет среди сельского населения. Также рассмотрено участие и роль органов государственной власти, партии, финансовых структур, Тувинского торгово-промышленного банка, Комитета советских граждан в организации размещения облигаций среди населения Тувы.

Ключевые слова: Тувинская Народная Республика; история Тувы; Тува; экономика Тувы; советский период; государственные займы; облигация; бюджет; подписка на заем; конверсия займов

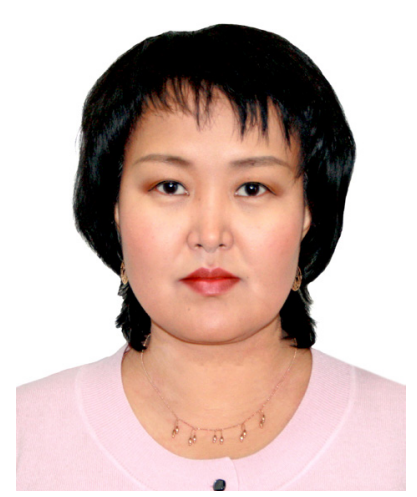

Для цитирования:

Харунова М. М.-Б., Харунов Р. Ш., Базыр Р. Н. Государственные внутренние займы Тувинской Народной Республики и СССР в Туве (1920-1940 гг.) // Новые исследования Тувы. 2020. № 3. С. 20-34. DOI: https://www.doi.org/10.25178/nit.2020.3.2

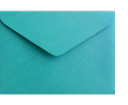

Харунова Марианна Монге-Байыровна - кандидат исторических наук, ведущий научный сотрудник лаборатории математического моделирования Тувинского института комплексного освоения природных ресурсов СО РАН. Адрес: 667007, Россия, г. Кызыл, ул. Интернациональная, д. 117А. Тел.: +7 (394-22) 6-62-18. Эл. адрес: ondar18@mail.ru

Харунов Рамиль Шатмуратович - кандидат исторических наук, заведующий филиалом Алдын Дошка Национального музея им. Алдан-Маадыр Республики Тыва. Адрес: 667000, Россия, г. Кызыл, ул. Титова, д. 30. Тел.: +7 (394-22) 2-28-04. Эл. адрес: ramar33@mail.ru

Базыр Руслана Николаевна - заместитель директора Национального архива Республики Тыва. Адрес: 667010, Россия, г. Кызыл, ул. Кечил-оола, д. 91. Тел.: +7 (394-22) 5-63-15. Эл. адрес: rnb-х@ mail.ru

KHARUNOVA, Marianna Monge-Bairovna, Candidate of History, Leading Research Fellow, Laboratory of mathematical modeling, Tuvinian Institute for Exploration of Natural Resources, Siberian Branch, Russian Academy of Sciences. Postal address: 117A Internatsionalnaya St., 667010 Kyzyl, Russian Federation. Tel.: +7 (39422) 2-28-04.E-mail: Ondar18@mail.ru ORCID ID: 0000-0002-9011-2262

KHARUNOV, Ramil Shatmuratovich, Candidate of History, Head, Aldyn-Doshka branch, Aldan-Maadyr National Museum of the Republic of Tuva. Postal address: 30 Titov St., 667000 Kyzyl, Russian Federation. Tel.: +7 (394-22) 2-28-04. E-mail: ramar33@mail.ru ORCID ID: 0000-0001-7940-5972

BAZYR, Ruslana Nikolaevna, Deputy Director, National Archives of the Republic of Tuva. Postal address: 91 Kechil-ool St., 667010 Kyzyl, Russian Federation. Tel.: +7 (394-22) 5-63-15.E-mail: rnb-x@mail.ru ORCID ID: 0000-0002-5305-3275 


\title{
Tuvan People's Republic's and USSR's Domestic Loans in Tuva, 1920s - 1940s
}

\author{
Marianna M.-B. Kharunova \\ Tuvinian Institute for Exploration of Natural Resources, Siberian Branch of RAS, Russian Federation, \\ Ramil Sh. Kharunov \\ Aldan-Maadyr National Museum of the Republic of Tuva, Russian Federation,
} Ruslana N. Bazyr

National Archives of the Republic of Tuva, Russian Federation

\begin{abstract}
In the 1930s-40s, the Government of the People's Republic of Tuva (PRT) followed the Soviet practices of using personal savings and enterprises' resources to raise funds to accelerate the republic's economic advance and reinforce its agricultural sector. To take control of these resources, public bonds were issued.

This article, making use of materials preserved at the National Archives of the Republic of Tuva, the 1930s-40-s regional newspapers and collections of the Aldan-Maadyr National Museum of Tuva, for the first time ever attempts to present an overall picture of the issuance, placement and circulation of the USSR and TPR public bonds in the territory of Tuva, as well as of how the borrowed funds contributed to the republic's economy.

The first USSR public bonds (1927, 1928, 1929, 1930 issues) were placed among Soviet professionals on an assignment in Tuva, and among residents of the Russian Self-Administering Workers' Colony (RSWC). Later on, the Government of Tuva widely used public bonds issued by the USSR. After TPR's accession to the USSR, the Tuvan government bonds issued in 1942 and 1943 were converted into those issued through the $3^{\text {rd }}$ Public War Loan of the USSR.

The article analyzes various methods of the bond placement. For instance, there were planned actions with mandatory bond purchase targets, "Socialist competitions" and obligatory subscription to loans through labor collectives. The bonds were also sold to rural population for cash. The authors also examine the involvement and role of the TPR government and party organs, financial sector, the Tuvan Bank of Industry and Trade and the Committee of Russian Citizens in the campaign of bond placement among the population of Tuva.
\end{abstract}

Keywords: TPR; USSR; public loan; bond; budget; loan subscription; bond conversion

\section{For citation:}

Kharunova M. M.-B., Kharunov R. Sh. and Bazyr R. N. Gosudarstvennye vnutrennie zaimy Tuvinskoi Narodnoi Respubliki i SSSR v Tuve (1920-1940 gg.) [Tuvan People's Republic's and USSR's Domestic Loans in Tuva, 1920s - 1940s]. New Research of Tuva, 2020, no. 3, pp. 20-34. (In Russ.). DOI: https://www.doi.org/10.25178/nit.2020.3.2

\section{Введение}

Во втором томе второго издания «Истории Тувы» есть только одна строчка, посвященная облигациям Тувинской Народной Республики (ТНР): «В 1942 и 1943 гг. правительство ТНР выпустило государственные внутренние выигрышные займы с целью увеличения помощи фронту» (История, 2007: 378). Эта лаконичная информация не отражает массива данных об объемных процессах по формированию рынка ценных бумаг, протекавших в республике с 1920-х по 1940-е годы.

Несмотря на большое количество исследований, посвященных бюджету ТНР, финансовой сфере государства, в том числе и авторов статьи (Иезуитов, 1956; Тульчинский, 1961; Тульчинский, Каплунов, 1972; Копеел, 1981; Аранчын, 1982; Бичелдей, 2009; Ананьин, Рогов, 2014; Харунова, Харунов, Санчай, 2019; Харунова, Харунов, 2019), тем не менее, тема облигаций (ценных бумаг) до сих пор не становилась предметом для исследований.

В данной статье мы попытаемся раскрыть основное содержание и суть исторических событий, связанных с размещением и обращением государственных внутренних займов СССР на территории Тувы и выпуском государственных внутренних займов ТНР (конец 1920-х - 1944 гг.), а также оценить значение полученных заемных средств для развития народного хозяйства республики. 
Источниковую базу нашего исследования составили материалы республиканских газет «Тувинская правда», «Шын», «Вперед» 1930-1940 гг., а также документы Тувинского торгово-промышленного банка 1930-х гг., хранящиеся в фондах Национального архива Республики Тыва (НА РТ, ф. 102, оп. 1). На страницах газет размещались постановления о выпуске облигаций, призывы к подписке, итоги розыгрышей, информация о проведении конверсии займов, а также статьи М. Самбу, работавшего министром финансов ТНР в 1932-1933, 1938-1944 гг., работников Правления Тувинбанка Х. Тоткана, Г. Лысенко и др. о значении государственных займов в период Великой Отечественной войны ${ }^{1}$, об итогах их реализации и др. ${ }^{2}$ В архивных документах представлены материалы об особенностях реализации облигаций советских госзаймов на территории ТНР, а также вопросы создания собственно тувинских облигаций, финансовая отчетность и др.

\section{Первые советские облигации в Туве}

Первые облигации государственных займов СССР получили распространение среди командированных в Туву советских специалистов и местных жителей Русской Самоуправляющейся Трудовой Колонии (РСТК) на территории ТНР, которые с 1942 г. получили двойное гражданство - тувинское и советское (Моллеров, 1989).

В ведомости о движении и остатках облигаций государственных займов в Тувинском ТорговоПромышленном банке (Тувинбанк), на 1 декабря 1931 г. перечисляются:

1. Государственный внутренний 10\% выигрышный займ 1927 г.;

2. Государственный внутренний 6\% выигрышный займ индустриализации народного хозяйства СССР 1927 г.;

3. Второй государственный внутренний выигрышный займ индустриализации народного хозяйства СССР 1928 г.;

4. Государственный внутренний выигрышный займ укрепления крестьянского хозяйства 1928 г. (НА РТ, ф. 102, оп. 1, д. 66, л. 18);

5. Третий государственный внутренний выигрышный займ индустриализации народного хозяйства СССР 1929 г.;

6. Государственный внутренний беспроцентный выигрышный займ 1929 г.;

7. Государственный внутренний займ «Пятилетка в четыре года» 1930 г.;

8. Государственный внутренний 9\% выигрышный займ 1930 г. (НА РТ, ф. 102, оп. 1, д. 160, л. 14).

Ценные бумаги Советского государства в 1920-е годы были выгодными для населения: приносили 8-10\% годового дохода своим владельцам по купонам (процентам); регулярно проводились тиражи выигрышей; доходы освобождались от налогов и сборов, облигации принимались в уплату налогов и участвовали в ссудных операциях; погашались вовремя в указанные сроки.

\section{Соглашения об условиях размещения займов СССР в ТНР}

С началом 1930-х годов к продаже советских облигаций активно подключилось руководство Тувинской Аратской Республики (ТАР $)^{3}$. Были заключены четыре соглашения об условиях размещения государственных займов СССР («Пятилетка в четыре года» 1930 г., «Третьего решающего года пятилетки» 1931 г., «Четвертого завершающего года пятилетки» 1932 г., «Вторая пятилетка выпуск первого года» 1933 г.) на территории ТАР (соглашения были заключены 30 декабря 1930 г., 29 марта и 19 ноября 1932 г., 19 декабря 1933 г.). (НА РТ, ф. 102, оп. 1, д. 171, л. 37).

С чем связан этот энтузиазм мы можем понять из текста, сохранившегося в фондах НА РТ «Соглашения об условиях размещения государственных займов СССР на территории ТАР», подписанного

\footnotetext{
${ }^{1}$ Самбу М. М., Ларионов К. Значение государственных займов в период Великой Отечественной войны // Тувинская правда.1943, №65 от 19 июня. С. 3.

${ }^{2}$ Самбу М. М. Итоги реализации Госзайма ТНР 1943 года в помощь фронту // Тувинская правда. 1943, № 92 от 27 августа. С. 2.

${ }^{3}$ Названия государства были закреплены в его конституциях: Танну-Тува улус - с 1921 г.; Танну-Тувинская Народная Республика - с 1924 г.; Тувинская Народная Республика - с 1926 г.; Тувинская Аратская Республика - с 1930 г.; Тувинская Народная Республика - с 1941 г. (Конституции Тувы, 1999: 24-93).
} 
19 декабря 1933 г. Председателем Совета министров ТАР Сатом Чурмит-Дажы и Полномочным представителем СССР в ТАР Никифором Васильевичем Поповым. Данный документ посвящен размещению облигаций займа СССР «Вторая пятилетка выпуск первого года» (1933 г.), и согласно статье второй данного соглашения, все поступившие к 1 сентября 1934 г. средства от займа на территории Тувы должны быть предоставлены республике в виде ссуды сроком на 10 лет под 5\% годовых (НА РТ, ф. 102, оп. 1, д. 171, л. 38). Указанные проценты Правительство ТАР должно было выплачивать Правительству СССР через Тувинбанк ежегодно, начиная с 1 октября 1934 г. Погашение самой ссуды должно производиться Правительством ТАР через тот же банк ежегодно, в течение пяти лет, равными долями, начиная с 1 октября 1939 г. по 1 октября 1944 г. включительно.

В статье четвертой документа предусматривались изменения условий ранее подписанных соглашений от 29 марта и от 19 ноября 1932 г. о размещении государственных займов СССР на территории ТАР «Пятилетка в четыре года» (1, 2 и 3 выпусков). Согласно этим изменениям, начиная с платежа 1933 г., размер процента по ссудам, выданным в связи с размещением на территории ТАР трех выпусков государственного внутреннего займа «Пятилетка в четыре года», снижался с $10 \%$ до 5\%. При этом порядок и сроки выплаты процентов оставались без изменений (НА РТ, ф. 102, оп. 1, д. 171, л. 38).

\section{Механизм распространения советских облигаций в ТНР}

Размещение каждого займа сопровождалось широкой пропагандистской кампанией политической направленности. Акценты ставились на выгодность вложения средств в государственные бумаги и политическое значение развития народного хозяйства республики.

Рассмотрим механизм распространения советских облигаций на примере Государственного внутреннего займа СССР «Четвертого завершающего года пятилетки» (1932 г.). Данный процесс хорошо задокументирован в фонде № 102 НА РТ.

Первоначально было издано Постановление Совета министров ТАР о распространении займа СССР «Четвертого завершающего года пятилетки» среди трудящихся ТАР от 18 августа 1932 г. за подписью заместителя председателя Совета Министров ТНР Оюна Данчая, в соответствии с которым ставилась задача мобилизовать все средства страны посредством проведения широкого распространения среди населения займа «Четвертого завершающего года пятилетки» для развития народного хозяйства, животноводства, поднятия его товарности, укрепления существующих и организации новых госхозов, колхозов, МТС, дальнейшее промышленное, дорожное, сельскохозяйственное и культурное строительство (НА РТ, ф. 102, оп. 1, д. 144, л. 54).

Ранее распространенные займы СССР - «Пятилетка в четыре года» (1930 г.) и «Третий решающий год пятилетки» (1931 г.), в сумме: первый 187000 рублей и второй - 300000 рублей, полученные в долгосрочный кредит на 10 лет, уже были вложены в развитие республики.

Исходя из этого, Совет министров ТАР установил контрольную цифру для размещения займа «Четвертого завершающего года пятилетки» по республике 300000 рублей. Было решено просить Правительство СССР о том, чтобы сумма, вырученная от реализации займа, была предоставлена полностью в кредит на таких же условиях, как и предыдущие займы.

Для реализации займа и содействия госкредиту была организована постоянная центральная правительственная комиссия содействия, в составе: председателя Чульдума и членов - Самбу, Тани Камовой, Бузина, Шагдыр-Суруна, Далай-Серена, а также представителя от русской части (его фамилия в документе не указана). Во всех хошунах, приисковых управлениях и учреждениях также организовывались постоянные комиссии содействия госкредиту.

Займ реализовывался под лозунгами: «Каждый рабочий и служащий дает в заем «Четвертого завершающего года пятилетки» свой трехнедельный заработок на дело некапиталистического социалистического строительства ТАР», «Каждый колхозник - свой трехнедельный доход», «Единоличник, равняйся на колхозника - подпишись на заем не менее своего трехнедельного дохода», «Все, как один, на выполнение подписки» (там же).

Между трудовыми коллективами, населенными пунктами, колхозами, хошунами проводились соревнования по размещению займа. Руководители учреждений, предприятий и колхозов несли персональную ответственность за своевременную реализацию займа и сдачу денег в Тувинбанк, как по наличному расчету, так и по коллективной подписке. Крестьяне единоличники и неорганизованное население покупали займ за наличный расчет. 
К развертыванию кампании по реализации займа было решено приступить с 1 сентября с таким расчетом, чтобы первый взнос по подписке поступил 15 сентября. Срок погашения займа по коллективной подписке устанавливался 10 месяцев, считая со дня первого взноса, т. е. 15 сентября 1932 г. и до 30 июня 1933 г. (НА РТ, ф. 102, оп. 1, д. 144, л. 55.)

Все трудящиеся должны быть подписчиками займа. Были определены контрольные цифры по г. Кызылу, хошунам, приискам и госхозам, опубликованные в газете «Вперед». В таблице 1 приведены суммы, установленные для подписчиков.

Таблица 1. Плановые суммы подписки на займ «4-го завершающего года пятилетки», 1932 г. ${ }^{1}$

Table 1. Planned subscriptions for the "4th and final year of the 5-year plan" loan, 1932.

\begin{tabular}{|c|l|c|}
\hline$N^{o}$ & \multicolumn{1}{|c|}{ Территория } & Сумма (руб.) \\
\hline 1 & Город & 121000 \\
\hline 2 & Хошуны & 115000 \\
\hline 3 & Прииски & 54000 \\
\hline 4 & Госхозы & 10000 \\
\hline \multicolumn{2}{|l}{ Итого } & 300000 \\
\hline
\end{tabular}

Среди населения республики проводилась массовая разъяснительная работа по условиям займа, которые были типовыми для всех трех выпусков облигаций «Пятилетка в четыре года». Займ устанавливался на 10 лет в виде двух типов выпуска. Один выпуск являлся процентным. Доход по облигациям этого выпуска устанавливался исключительно в виде процентов, выплачиваемых по купонам регулярно в оговоренные сроки. Другой выпуск являлся беспроцентным выигрышным. В течение десятилетнего срока займа на каждую облигацию этого выпуска обязательно выпадал выигрыш.

Доходность займа определялась государством в среднем по 10\% годовых. По процентному выпуску держатель займа получал свой доход по купонам, срок которых наступал каждое 1 декабря, начиная с 1933 г. По беспроигрышному выпуску доход выплачивался в виде выигрышей (НА РТ, ф. 102, оп. 1, д. 144, л. 66).

По выигравшей облигации выплачивался только выигрыш. При выплате выигрыша от облигации отрезался специальный контрольный талон. Облигация возвращалась владельцу с последующим погашением через три года с момента выпадения на нее выигрыша (НА РТ, ф. 102, оп. 1, д. 144, л. 67).

Последним абзацем условий распространения займа являлся призыв: «Дадим государству свой трехнедельный заработок! Рабочие, колхозники и служащие, обеспечим стопроцентное участие в подписке на заем «Четвертого завершающего года пятилетки» (НА РТ, ф. 102, оп. 1, д. 144, л. 68).

Трудно было совместить требование инструкции министерства финансов и Тувинбанка о порядке и условиях реализации займа, в которой говорилось, что «реализация проводится на основе полной добровольности методами широкой агитмассовой работы» (НА РТ, ф. 102, оп. 1, д. 144, л. 71), с контрольными цифрами и требованием охватить всех трудящихся подпиской на займ. В Каа-Хемском хошунном управлении (п. Знаменка) отнеслись к размещению займа с «революционной прямотой» и 22 сентября 1932 г. управление разослало письма жителям поселка Медведевка с требованием в обязательном порядке до 1 октября приобрести облигации займа на 500 либо 300 руб. В противном случае управление грозилось привлечь к судебной ответственности по законам ТНP (HA PT, ф. 102, оп. 1, д. 144, л. 67).

Минфин ТНР в ответ на жалобы граждан отреагировал быстро, отметив недопустимость применения методов, подрывающих доверие населения, и предлагал проводить реализацию займа в добровольном порядке путем массовой разъяснительной работы (НА РТ, ф. 102, оп. 1, д. 144, л. 71).

Несмотря на подобные прецеденты, среди коллективов проводились соревнования по подписке на займ. Обычно все проходило по одной схеме: работник расписывался в подписном листе по сумме приобретаемых облигаций (трехнедельный заработок, а в следующем займе - уже за месяц) и получал закрепительный талон на право получения облигаций после выплаты всей суммы подписки. Максимальный срок рассрочки платежа составлял 10 месяцев и платеж производился удержанием

\footnotetext{
1 Чульдум. Все трудящиеся должны быть подписчиками займа. Выполним контрольные цифры // Вперед, 1932. № 27 от 23 сентября. С. 1.
} 
из зарплаты в счет погашения подписки на займ. Часть облигаций, как правило, среди сельского населения, распространялась за наличный расчет. Активное участие в пропаганде подписки на займы СССР принимали Комитеты советских граждан ${ }^{1}$ (История Тувы, 2007: 219).

Последним широко распространенным на территории ТНР был советский займ «Вторая пятилетка выпуск первого года» 1933 г. По опыту прошлых лет Совет министров ТНР выпустил постановление о распространении займа, в котором говорилось, что в целях развития основной отрасли народного хозяйства - животноводства, укрепления госхозов, для реализации намеченного плана транспортного и дорожного строительства, дальнейшего развития кустарной промышленности и окончания намеченного промышленного строительства (кожевенный завод, лесопильный завод и др.) поставлена задача мобилизации средств путем широкого распространения займа среди жителей республики (НА РТ, ф. 102, оп. 1, д. 182, л. 57).

В документе отмечалось, что держателям займов, распространенным ранее, в 1931 г. была выплачена 21000 руб., в 1932 г. - 36500 руб., и за 6 месяцев 1933 г. 36700 руб. процентами по купонам и выигрышам.

В соответствии с этим постановлением была утверждена контрольная цифра распространения займа «Второй пятилетки» по республике в 300000 рублей с разбивкой по приискам, городу и хошунам.

Таблица 2. Плановые суммы подписки на займ «Второй пятилетки», 1933 г. ${ }^{2}$

Table 2. Planned subscriptions to the "2nd 5-year plan"loan, 1933.

\begin{tabular}{|c|l|c|}
\hline \multicolumn{1}{|c|}{ Территория } & Сумма (руб.) \\
\hline 1 & Город & 126000 \\
\hline 2 & Хошуны & 105000 \\
\hline 3 & Прииски & 54000 \\
\hline 4 & Госхозы & 15000 \\
\hline Итого & & 300000 \\
\hline
\end{tabular}

Центральной комиссии содействия госкредита было предложено выделить соответствующее количество работников для проведения кампании по хошунам. Ответственность за реализацию займа возлагалась на эту же комиссию.

Реализация займа должна была сопровождаться разъяснительной работой под лозунгом: Каждый рабочий и служащий свой месячный заработок взаймы на выполнение намеченного строительства. Каждый колхозник - свой месячный доход, единоличник, равняйся на колхозника» (HА РТ, ф. 102, оп. 1, д. 182, л. 58).

Как и ранее, на руководителей учреждений, предприятий, приисков, хошунных управлений, госхозов, колхозов возлагалась персональная ответственность за своевременную реализацию займа и сдачу денег в Тувинбанк. Срок погашения займа по коллективной подписке устанавливался в 10 месяцев - с 1 октября 1933 г. по 15 июля 1934 г. (там же).

В результате активной кампании установленная Советом министров ТНР сумма в 300000 руб. была выполнена к 23 января 1934 г. (НА РТ, ф. 102, оп. 1, д. 182, л. 126). Это было последнее массовое мероприятие по распространению советских займов на территории ТНР.

\section{Финансовые результаты от размещения госзаймов СССР в ТНР}

Большая часть тиражей государственных займов СССР была распространена добровольно-принудительными методами по подписке среди населения. Так, облигации «Пятилетка в четыре года» планировалось распространить на сумму 125000 руб., а реализовали на 187000 руб. (на 140000 руб. по подписке). «Третий решающий год пятилетки» по плану составлял 300000 руб., а был распространен на 330000 руб. (210 000 руб. по подписке). По итогам реализации «Четвертого завершающего года

\footnotetext{
${ }^{1}$ Комитеты советских граждан - органы самоуправления постоянно проживавших в Туве советских граждан, созданные 24 мая 1932 г. по Соглашению между ТНР и СССР. В феврале 1942 г. КСГ преобразованы в хуралы трудящихся (История Тувы, 2007: 215, 227).

2 Данные для таблицы взяты из публикации: Контрольные цифры по реализации займа «Второй пятилетки» (первого выпуска) // Вперед. 1933. № 70 от 15 сентября. С. 3.
} 
пятилетки» общая сумма распространения займа превысила плановую и составила 310670 руб. (234 640 руб. по подписке) (НА РТ, ф. 102, оп. 1, д. 144, л. 92). Займ «Вторая пятилетка выпуск первого года» принес еще 300000 руб. В сумме 1127670 руб. поступило в бюджет республики в качестве ссуд от размещения государственных внутренних займов СССР среди населения ТНР. Чтобы понять относительную величину этой суммы, достаточно привести цифру бюджета республики за 1935 г. 2818700 руб. (Тульчинский, 1961:272).

Необходимо отметить, что советское правительство также предоставляло республике кредиты на льготных условиях, неоднократно списывая задолженность. В 1938 г. было списано 3050,4 тыс. руб., что составляло 45,8\% расходов бюджета ТНР (Экономика Тувинской АССР, 1973: 78).

На что же расходовались поступившие средства? В передовице газеты «Вперед» № 69 от 11 сентября 1933 г., посвященной распространению займа «Вторая пятилетка выпуск первого года», подведены итоги за три предыдущие кампании. «За последние три года Правительство ТНР в народное хозяйство вложило займовых средств 820000 рублей. ... Причем, дорожное строительство, это не только тракт граница - Кызыл, это только часть одной большой задачи, поставленной Правительством ТНР. Дорожное строительство это и тракт Шагонар - Чадан, и тракт Чадан - Кызыл-Мажалык. Это только в направлении западной части республики. Хорошая дорога, проезжая для автотранспорта во все концы республики - такова основная задача в области дорожного строительства. Куплены 24 автомашины, постройка гаражей, госхозы, промышленное строительство, рост школ, больниц и т. д.»ํ.

В архивных фондах сохранился ряд обязательств Правительства ТНР по погашению средств, поступивших от ссуды за счет реализации советских облигаций. Например, сроки погашения ссуды за облигации «Пятилетка в четыре года» 1930 г. приведены в таблице 3.

Таблица 3. Сроки погашения ссуды за облигации «Пятилетка в четыре года» 1930 г.

Table 3. Maturity dates for the "Five-year plan in four years" bonds, 1930.

\begin{tabular}{|c|c|c|}
\hline$N^{o}$ & Дата & Сумма \\
\hline 1 & 01.12 .1936 & 24415 руб. \\
\hline 2 & 01.12.1937 & 24415 руб. \\
\hline 3 & 01.12 .1938 & 41317 руб. \\
\hline 4 & 01.12 .1939 & 48830 руб. \\
\hline 5 & 01.12 .1940 & 48829 руб. 38 коп. \\
\hline \multicolumn{2}{|c|}{ Итого } & 187806 руб. 38 коп. \\
\hline
\end{tabular}

(НА РТ, ф. 102, оп. 1, д. 178, л. 2).

1 октября 1932 г. Правительство обязывалось погасить ссуду от государственного займа СССР «Пятилетка в четыре года» выпуска 3-го решающего года 150000 рублей в течение 9 лет и направить полученные средства на развитие народно-хозяйственного строительства (НА РТ, ф. 102, оп. 1, д. 178, л. 4).

По обязательству от 18 июля 1933 г. Министерство финансов в лице министра М. М. Самбу, из средств реализованного на территории ТНР займа «Четвертого завершающего года пятилетки», получило ссуду в сумме 100000 руб. на нужды народного хозяйства ТНР, в частности на дорожное строительство и развитие животноводства (НА РТ, ф. 102, оп. 1, д. 178, л. 6).

\section{Конверсия (обмен) госзаймов СССР в 1936-1939 годах}

В 1936 г. Правительство СССР провело конверсию (обмен) всех предыдущих действующих займов на один - «Государственный внутренний займ второй пятилетки (выпуск четвертого года)», который фактически ухудшил положение займодержателей, снизив ежегодный процент с 8 до 4 и увеличив срок погашения облигаций с десяти до двадцати лет.

В газете «Вперед» (печатном органе Комитетов советских граждан) № 79 от 18 ноября 1936 г. в статье «О порядке конверсии (обмена) займов среди советских граждан, проживающих в ТАР» дано разъяснение Консульского отдела полпредства СССР в ТАР о «Постановлении Советского правительства от 1 июля 1936 г. о выпуске нового внутреннего займа и конверсии ранее выпущенных займов»².

${ }^{1}$ Полностью распространим контрольную цифру // Вперед. 1933. № 69 от 11 сентября. С. 1.

${ }^{2}$ О порядке конверсии (обмена) займов среди советских граждан, проживающих в ТАР // Вперед. 1936. № 79 от

18 ноября. С. 4. 
В соответствии с этим решением Тувинбанк и его отделения приступили с 25 сентября 1936 г. к подготовительной работе по проведению конверсии (обмена) займов среди советских граждан, проживавших в ТАР. При этом граждане, не сдавшие Тувинбанку свои облигации для обмена, были лишены этой возможности, т. к. все облигации прежних займов с 1 сентября 1937 г. аннулировались и к обмену не принимались (НА РТ, ф. 102, оп. 1, д. 305, л. 23 об.).

В связи с проведением конверсии займов решением Тувинбанка и управления связи для составления списков по обмену облигаций был произведен объезд всех поселков Тоджинского хошуна, прииска Харал и поселков Каа-Хемского хошуна, произведена массовая проверка выигрышей по всем выпускам госзаймов. В результате проверок было оплачено выигрышей по облигациям и срочным купонам: на Тодже - 2534 акша, в том числе свыше 500 акша тувинским гражданам; на Харале - 1187 акша; в Знаменке - 1993 акша; в Медведевке - 573 акша ${ }^{1}$.

В 1938-1939 гг. была проведена конверсия предыдущих займов на выпуск «Государственный внутренний займ второй пятилетки (выпуск четвертого года)» и среди тувинского населения. В итоге на руках у жителей Тувы остались только облигации данного займа (НА РТ, ф. 102, оп. 1, д. 418, л. 1).

\section{Добровольная сдача облигаџии госзаймов СССР в фонд обороны в 1941-1944 годах}

Судьба большей части тиража «Государственного внутреннего займа второй пятилетки (выпуск четвертого года)» со штампом «Тувинбанка» определилась уже во время Великой Отечественной войны. Первые восемь облигаций (на сумму 1090 руб.) в качестве добровольных пожертвований для укрепления обороны СССР в связи с нападением на него фашистской Германии принес товаровед Тувинценкоопа Юневич. 3 июля 1941 г. данные облигации были направлены в Банк Внешней торговли СССР (НА РТ, ф. 102, оп. 1, д. 585, л. 1).

Это мероприятие сразу же приобрело массовый характер и на протяжении 1941-1944 гг. Тувинбанк еще девять раз направлял облигации, собранные «в основном гражданами ТНР и СССР и лишь в незначительной части различными учреждениями и организациями» для зачисления в Фонд обороны СССР (НА РТ, ф. 102, оп. 1, д. 585, л. 16).

Итоговая сумма оказалась значительной - 286365 руб. (таблица 4). Население Тувы и посредством личных сбережений внесло свой вклад в победу.

Таблица 4. Сумма облигаций «Государственного внутреннего займа второй пятилетки (выпуск четвертого года)», внесенных в фонд обороны.

Table 4. Total value of the "State internal loan of the 2nd five-year plan" bonds (issued in the 4th year).

\begin{tabular}{|c|c|c|}
\hline № & Дата отправки & Сумма (руб.) \\
\hline 1 & 03.07 .1941 & 1090 \\
\hline 2 & 06.10 .1941 & 53665 \\
\hline 3 & 15.12 .1941 & 74835 \\
\hline 4 & 31.12 .1941 & 47040 \\
\hline 5 & 31.03 .1942 & 54205 \\
\hline 6 & 30.06 .1942 & 26190 \\
\hline 7 & 30.12 .1942 & 12630 \\
\hline 8 & 31.03 .1943 & 11500 \\
\hline 9 & 31.12 .1943 & 4455 \\
\hline 10 & 30.12 .1944 & 775 \\
\hline & & 286385 \\
\hline
\end{tabular}

(НА РТ, ф. 102, оп. 1, д. 585, л. 43).

Почему же Правительство ТНР использовало государственные ценные бумаги СССР в 1920-1930 гг., а не выпустило собственные внутренние займы? Причин было много. Мы рассмотрим две из них.

Во-первых, это было сложно технически. В Туве не было опыта выпуска и размещения государственных внутренних займов и не было технических возможностей издания защищенных финансовых продуктов. Новые экономические реалии с трудом находили воплощение в народном хозяйстве республики, выбравшей некапиталистический путь развития.

\footnotetext{
${ }^{1}$ Яшин. О проведении конверсии займов // Вперед. 1936. № 79 от 18 ноября. С. 4.
} 
Во-вторых, государственные обязательства СССР пользовались доверием населения, обладали доходностью и высоким уровнем ликвидности, чего нельзя было гарантировать в случае выпуска внутреннего займа ТНР.

С 1934 г. Правительство ТНР отказалось от практики массового распространения государственных внутренних займов СССР среди населения республики. Это было связано с тем, что рос внутренний государственный долг по четырем предыдущим ссудам с повышением объемов средств на его обслуживание. К тому же в Туве в 1935 г. была проведена денежная реформа и введена национальная валюта - акша. Формирование собственной денежной системы в целом укрепило финансово-экономические институты, такие как налоговая, кредитная политика и государственный бюджет, а также основные отрасли экономики республики (Харунова, Харунов, 2019: 219). Хотя не все было гладко. Так в 1939 г. был финансовый кризис, когда даже армия республики была под угрозой сокращения, срочно понадобилась советская помощь.

\section{Выпуски 1942 и 1943 годов государственных внутренний займов ТНР}

Первые попытки выпустить государственный внутренний займ ТНР были предприняты в 1941 г. Об этом свидетельствует деловая переписка Полномочного представителя ТНР в СССР Сата Намчака с управляющим производством государственных знаков НКФ СССР в августе 1941 г. о принятии заказа на изготовление первых тувинских облигаций (НА РТ, ф. 100, оп. 1, д. 250, л. 87-88). От имени правительства ТНР Сат Намчак попросил как можно быстрее выполнить заказ, чтобы можно было начать реализацию займа в этом же году. Несмотря на эти планы, первый выпуск облигаций ТНР состоялся только в следующем году. В июне 1942 г. вышло Постановление Совета министров ТНР и Центрального комитета ТНРП о выпуске первого государственного внутреннего выигрышного займа. В постановлении говорилось, что:

«...в целях развития и подъема материального и культурного уровня аратских масс, усиления государ-

ственных резервов и дальнейшего укрепления оборонной мощи ТНР, необходимо:

1. Выпустить первый Государственный внутренний выигрышный займ в сумме 1.000 .000 акша.

2. Займ запустить сроком на 10 лет - с 1 декабря 1942 г. до 1 декабря 1952 г., из 4 \% годовых.

3. Облигации займа и доходы от них освободить от обложения государственными налогами и сборами.

4. Утвердить представленные министерством финансов условия выпуска Первого государственного внутреннего выигрышного займа.

5. Для размещения займа и руководства работой по займу образовать Центральную комиссию по Госзайму в составе:

Председатель комиссии - заместитель Председателя Президиума Малого Хурала ТНР тов. Базыр-Сат.

Члены комиссии - Председатель ЦК Профсоюза - Лопсан-Самбу, Министр финансов - Самбу.

6. Предоставить право Центральной комиссии по Госзайму образовывать комиссии по Госзайму при хошунных хуралах трудящихся и отдельных предприятиях и учреждениях.

7. Реализация займа среди сельского населения производится за наличный расчет по временным квитанциям, подлежащим обмену на облигации займа» (НА РТ, ф. 113, оп. 1, д.122, л. 57).

Далее последовало Постановление Совета министров ТНР о ходе размещения Первого государственного внутреннего выигрышного займа ТНР, в котором отмечалось, что займ, выпущенный на сумму 1000000 акша, успешно реализован на основе активного участия сельского населения, рабочих и служащих республики. На 1 сентября 1942 г. Государственный займ был реализован среди сельского населения за наличный расчет на сумму 403169 акша, среди рабочих и служащих на сумму 597712 акша, что в общей сумме составило 1000881 акша.

Хошунным комиссиям по размещению займа и хуралам трудящихся хошунов было поручено к 30 сентября 1942 г. полностью погасить задолженность по временным квитанциям. А с 5 октября 1942 г. Центральная комиссия по размещению займа начинала обмен проданных временных квитанций на облигации займа (НА РТ, ф. 113, оп. 1, д. 122, л. 47).

По инструкции об оплате выигрышей и стоимости выигравших облигаций «Первого государственного внутреннего выигрышного займа ТНР» общая сумма выигрышей, подлежавших выплате в течение 10 лет определялась в 338500 акша. Должно было пройти 20 тиражей (по два в год). Первый тираж, согласно объявлениям Минфина ТНР в газетах «Шын» и «Тувинская правда», состоялся 20 июня 1943 г.

Выигрыши от 25 до 250 акша выплачивались немедленно по предъявлении облигаций вместе со стоимостью самих выигравших облигаций. Выигрыши в 500 и 1000 акша считались крупными и вы- 
плачивались только после предварительной проверки Минфина ТНР. В постановлении упоминаются облигации достоинством в 10, 25 и 50 акша (НА РТ, ф. 165, оп. 1, д. 22, л. 31). В газете «Шын» была опубликована таблица выигрышей первого тиража внутреннего выигрышного займа THP1 .

В июле 1943 г. было принято решение о выпуске Государственного внутреннего беспроигрышного займа ТНР 1943 г. в помощь фронту. Займ выпускался в облигациях достоинством 100, 50, 25 и 10 акша сроком на десять лет с 1 ноября 1943 г. по 1 ноября 1953 г. ${ }^{2}$

В условиях высокого подъема патриотизма в Великой Отечественной войне выигрышные займы ТНР были размещены с большим успехом. Каждый понимал, что «... народные сбережения, отданные взаймы государству, будут дополнительным ударом по врагу»³.

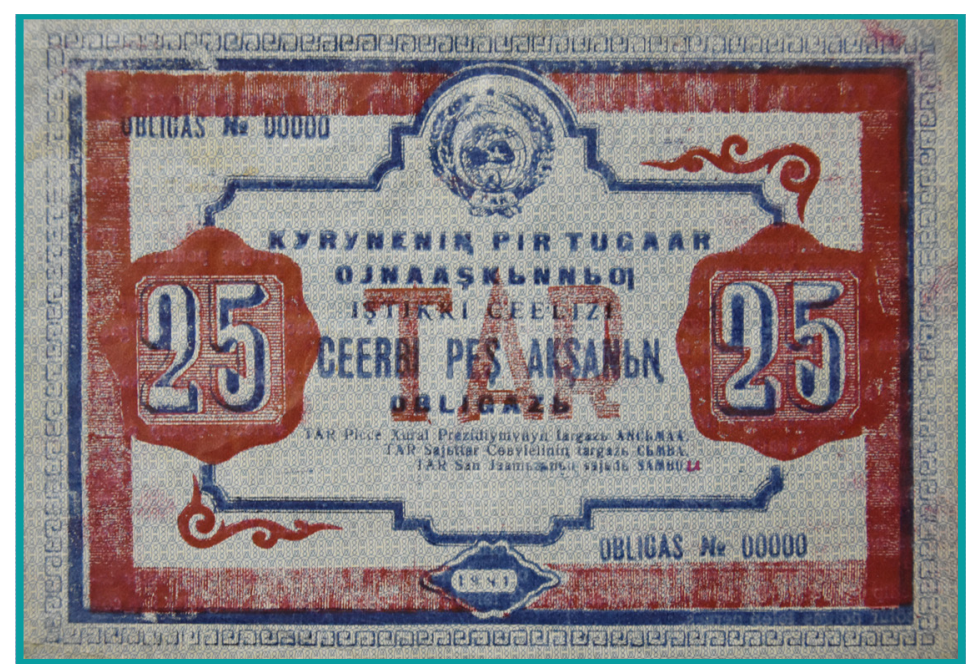

Население Тувы с большим энтузиазмом участвовало в приобретении облигаций и уже 26 августа 1943 г. Совет министров ТНР в своем постановлении подвел итоги реализации второго займа в сумме 1156430 акша 4 . Благодаря подписке на государственный внутренний займ и сбору наличных денег в фонд обороны СССР было собрано более 2 млн акша (Копеел, 1981: 88). В 1943 г. на средства, собранные с населения и выделенные из государственного бюджета Республики, была куплена и передана Красной Армии авиаэскадрилья «Тувинский народ - фронту» в составе десяти боевых самолетов (Иезуитов, 1956: 124).

Фото 1. Облигация на 25 акша 1941 г., проект.

НМ РТ, ф.10, ДПИ, шкаф №15, полка №13, коробка 1.

Фото А. Д. Куулар, 2018 г. Photo 1. A 25 aksha bond, 1941, obverse, draft version, NM RT, f. 10, DPI, Cab. 15, Shelf 13, Box 1.

Photo by A. D. Kuular, 2018.

Фото 2. Облигация на 25 акша 1941 г., оборотная сторона. НМ РТ, ф. 10, ДПИ, шкаф № 15, полка № 13, коробка 1. Фото А. Д. Куулар, 2018 г. Photo 2. A 25 aksha bond, 1941, reverse, draft version, $N M R T, f .10$, DPI, Cab. 15, Shelf 13, Box 1. Photo by A. D. Kuular, 2018.

\section{TAR-NLN KYRYNENIN PIR TUGAAR OJNAASKLNNBO} ISTIKKI CEELIZININ -CURUMU

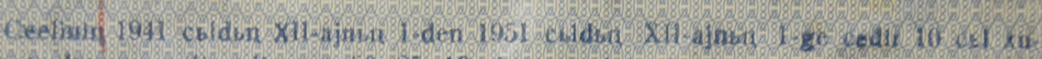

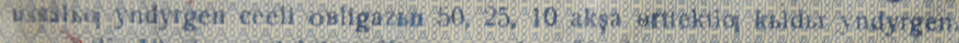

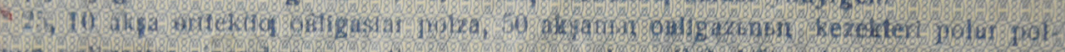

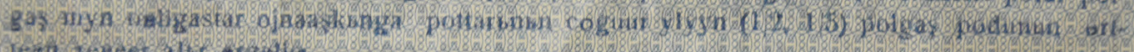

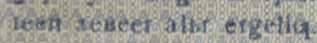

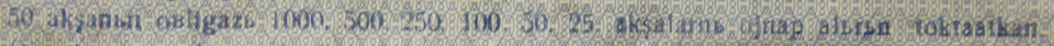

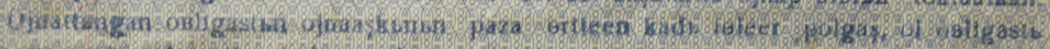

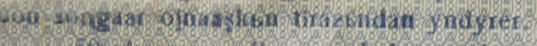

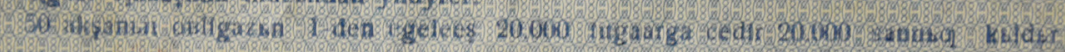
youlsterex.

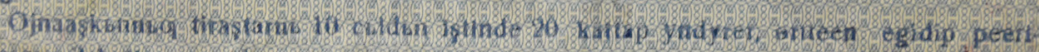
nif Miran 3 kathap corudar.

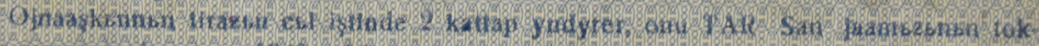

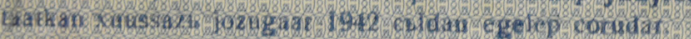

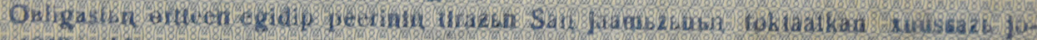

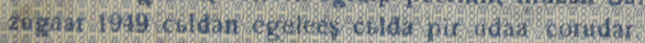

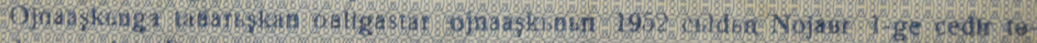

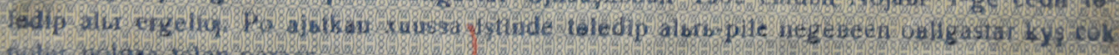

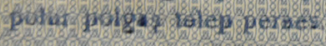

\footnotetext{
${ }^{1}$ TAR-nьn Kyrynenin Pir Tugaar Ojnaaşkьnnьø Iştikki Ceeşkini [Таблица выигрышей первого тиража внутреннего выигрышного займа ТНР] // Шын. 1943. № 53 от 22 июня. С. 6. (На тув. яз.).

${ }^{2}$ Чымба С. Т. О выпуске Государственного внутреннего беспроигрышного займа ТНР 1943 г. в помощь фронту // Тувинская правда. 1943. № 72 от 8 июля. С. 1 .

${ }^{3}$ Самбуу М. М., Ларионов К. Значение государственных займов в период Великой отечественной войны // Тувинская правда. 1943. № 65 от 19 июня. С. 3.

${ }^{4}$ Самбуу М. М. Итоги реализации госзайма ТНР 1943 года в помощь фронту // Тувинская правда. 1943. № 92 от 27 августа. С. 2.
} 


\section{НОВЫЕ ИССЛЕДОВАНИЯ ТУВЫ}

www.nit.tuva.asia
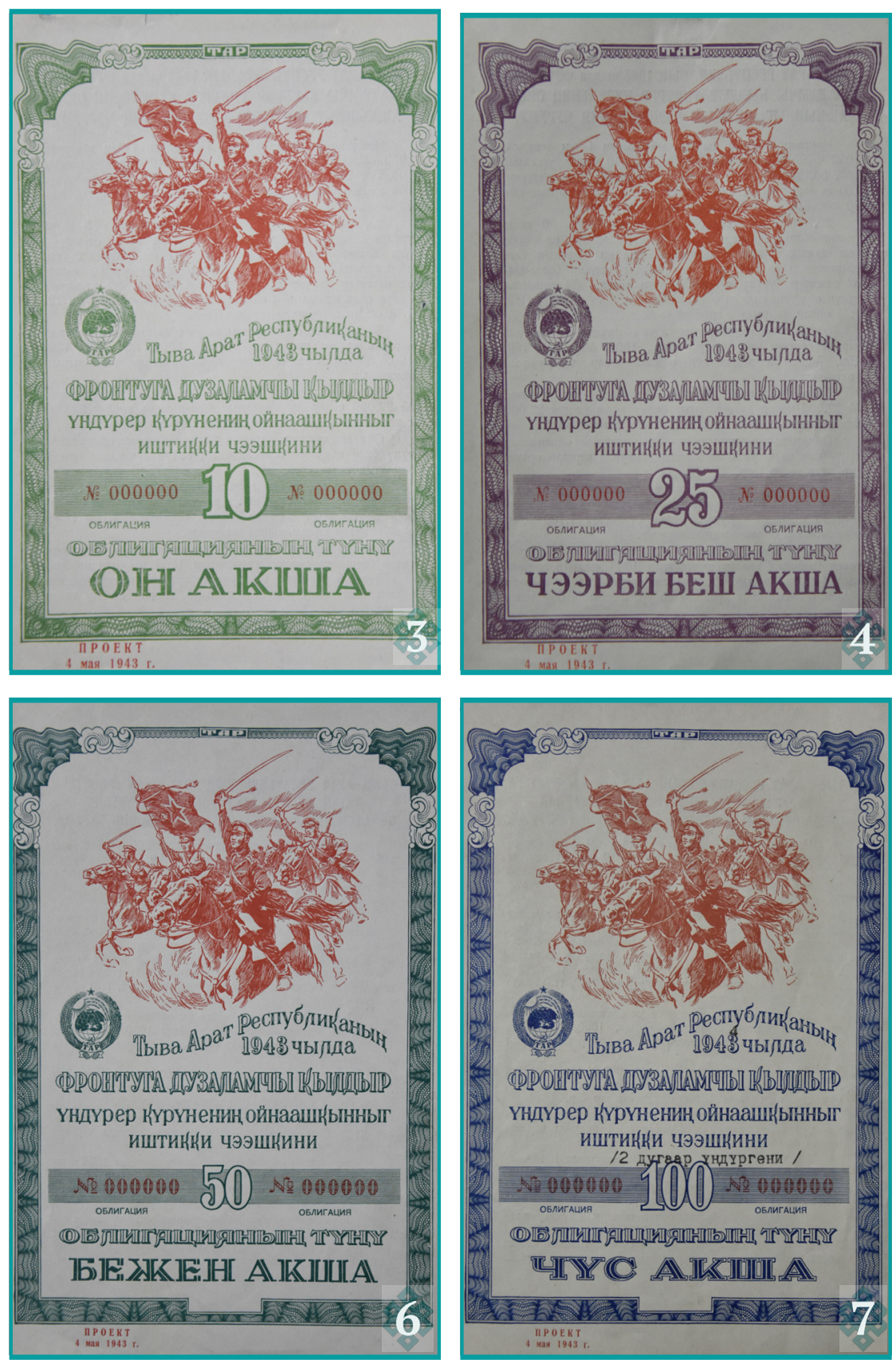

THE NEW RESEARCH OF TUVA

Novye issledovaniia Tuvy
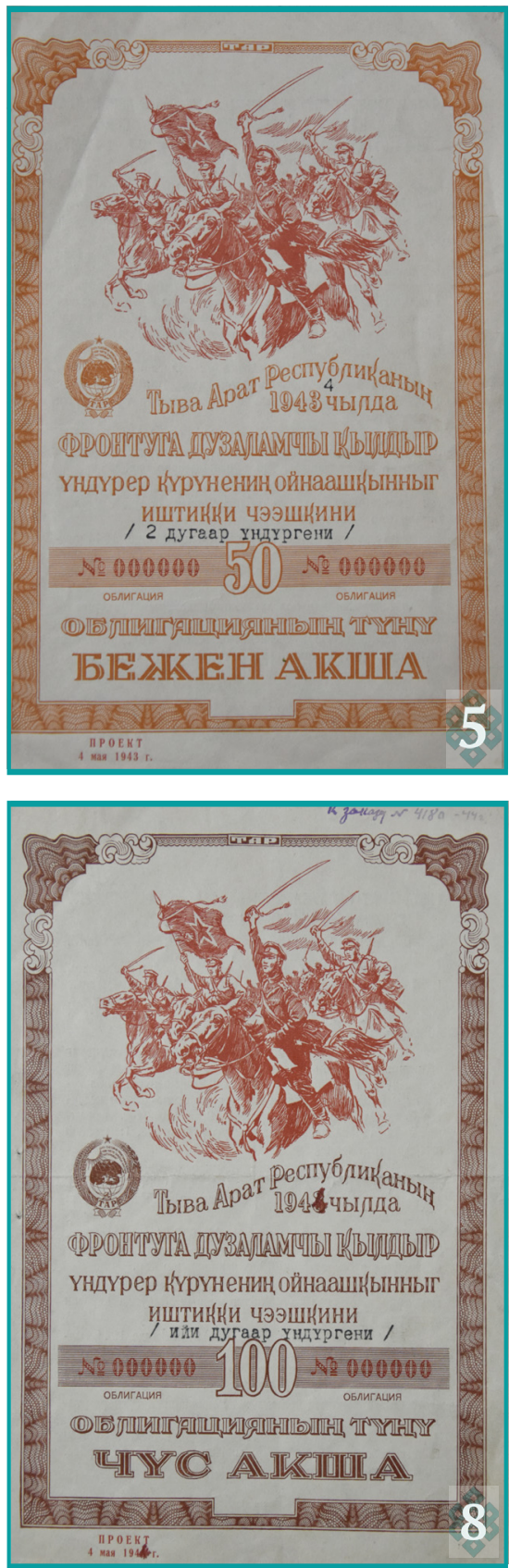

Фото 3-8:

3. Облигация на 10 акша 1943 г., проект; 4. Облигация на 25 акша 1943 г., проект;

5. Облигация на 50 акша 1943 г., светло-коричневая, проект;

6. Облигация на 50 акша 1943 г., сине-зеленая, проект;

7. Облигация на 100 акша 1943 г., синяя, проект; 8. Облигация на 100 акша 1943 г., коричневая, проект.

НМ РТ, ф. 10, ДПИ, шкаф № 15, полка №13, коробка 1. Фото А. Д. Куулар, 2018 г.

Photos 3-8:

3. A 10 aksha bond, 1943, obverse, draft version,

4. A 25 aksha bond, 1943, obverse, draft version,

5. A 50 aksha bond, 1943, obverse, light brown, draft version,

6. A 50 aksha bond, 1943, obverse, sea-green, draft version,

7. A 100 aksha bond, 1943, obverse, blue, draft version,

8. A 100 aksha bond, 1943, obverse, brown, draft version.

NM RT, f. 10, DPI, Cab. 15, Shelf 13, Box 1. Photos by A. D. Kuular, 2018. 


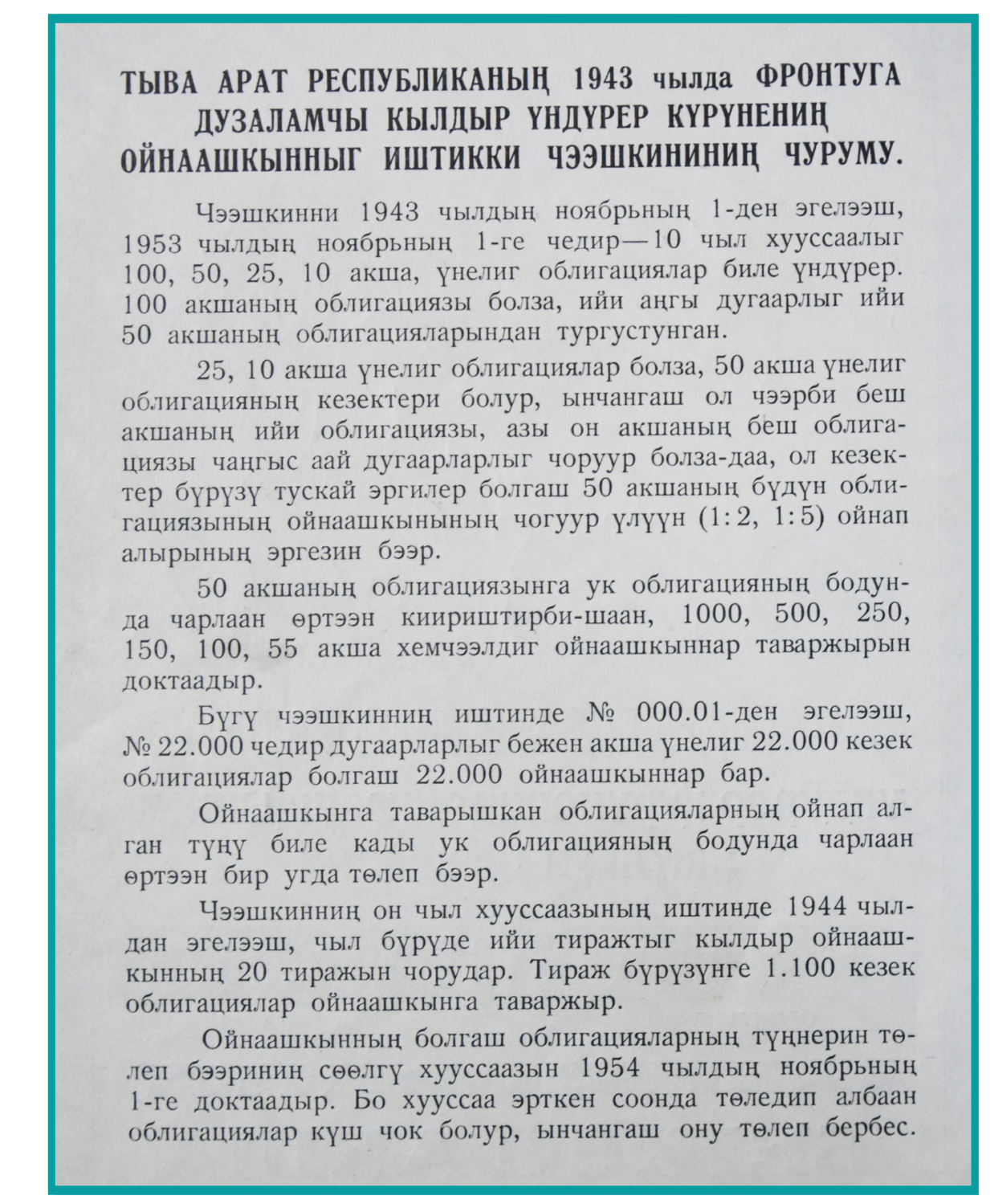

Фото 9. Оборотная сторона облигаций 1943 г. НМ РТ, ф. 10, ДПИ, шкаф № 15, полка № 13, коробка 1. Фото А. Д. Куулар, 2018 г.

Photo 9. 1943 bonds, reverse. NM RT, f. 10, DPI, Cab. 15, Shelf 13, Box 1. Photos by A. D. Kuular, 2018.

В коллекциях Национального музея им. Алдан-Маадыр Республики Тыва сохранились проекты облигаций внутреннего выигрышного займа ТНР, датированные 1941 г. и 1943 г. на 10, 25, 50 и 100 акша (фото 1-8). Некоторые из них выполнены в различных цветах. К сожалению, оригиналов облигаций ТНР первого и второго займов 1942 г. и 1943 г. в коллекциях музея и фондах архива не имеется.

На оборотной стороне облигаций 1943 г. был напечатан одинаковый текст на тувинском языке с разъяснениями по порядку розыгрыша облигаций данного выпуска (фото 9).

\section{Обмен облигаций после вхождения ТНР в состав СССР в 1944 г.}

После вхождения ТНР в состав СССР ситуация с облигациями кардинально поменялась. В апреле 1945 г. в «Тувинской правде» было опубликовано извещение исполнительного комитета областного Совета депутатов трудящихся Тувинской автономной области и Тувинского областного финансового отдела, в котором говорилось, что производится обмен облигаций Тувинских Государственных займов выпусков 1942 и 1943 гг. на облигации Третьего Государственного военного займа СССР по установленному обменному курсу валют -1 акша $=3$ рубля 50 копеек.

Населению рекомендовалось перед тем, как обменять облигации Тувинских займов, обязательно проверить их по таблицам тиражей выигрышей, так как выигравшие облигации обмену не под- 
лежали и предъявлялись в сберкассу или Госбанк для оплаты выигрышей не позднее 31 декабря 1945 г. Держатели облигаций обмениваемых займов могли по своему желанию при обмене получить облигации Третьего Государственного военного займа СССР любого достоинства (100, 50 и 25 рублей).

Все облигации Тувинских Государственных займов, не предъявленные для обмена до 31 декабря 1945 г., считались утратившими силу и после обозначенного срока обмену или оплате не подлежали ${ }^{1}$

\section{Заключение}

Благодаря объемным фондам Национального Архива Республики Тыва удалось восстановить забытую страницу социально-экономического развития в истории Тувы - о реализации государственных внутренних займов СССР и ТНР. При поддержке СССР в ТНР в 1930-е годы по соглашениям были размещены советские облигации госзаймов: «Пятилетка в четыре года» 1930 г., «Третьего решающего года пятилетки» 1931 г., «Четвертого завершающего года пятилетки» 1932 г., «Вторая пятилетка выпуск первого года» 1933 г.

Мобилизация финансовых ресурсов республики потребовала применения добровольных и принудительно подписных методов по реализации облигаций в Туве. Тем не менее, государственные займы пользовались успехом у населения, потому что сочетали в себе общегосударственные интересы и непосредственную выгоду займодержателей.

Вырученные средства от займов были получены Правительством ТНР в виде ссуды и потрачены на основные направления народного хозяйства - животноводство и дорожно-транспортную инфраструктуру.

Во второй половине 1930-х годов Правительство ТНР отказалось от практики массового распространения государственных внутренних займов СССР среди населения республики. Формирование собственной денежной системы укрепило финансово-экономические институты, такие как налоговая, кредитная политика и государственный бюджет. Не обошлось и без трудностей. В 1939 г. республика пережила финансовый кризис, выйти из которого смогла при помощи СССР. Впоследствии, остававшийся на руках у жителей республики тираж советского госзайма «Вторая пятилетка выпуск четвертого года 1936 г. (со штампом Тувинбанка)» на сумму 286385 рублей, был добровольно и патриотично сдан в фонд обороны СССР в 1941-1944 гг.

Опыт по размещению облигаций госзаймов СССР помог мобилизовать сбережения населения и средств предприятий в суровые годы Великой Отечественной войны на пользу республике. Выпуски государственных внутренних выигрышных займов ТНР 1942 и 1943 гг. пошли на укрепление оборонной мощи и отраслей народного хозяйства.

В связи с вхождением ТНР в состав СССР в октябре 1944 г., тиражи облигаций государственных внутренних выигрышных займов ТНР в 1945 г. были обменены на облигации Третьего Государственного военного займа СССР.

\section{СПИСОК ЛИТЕРАТУРЫ}

Ананьин, А. Я., Рогов, Г. И. (2014) Денежные знаки Тувы // Антиквариат, предметы искусства и коллекционирования. № 9 (119). С. 134-143.

Аранчын, Ю. Л. (1982) Исторический путь тувинского народа к социализму. Новосибирск : Наука. 337 с.

Бичелдей, К. А. (2009) Денежная реформа ТНР 1925-1940 гг. - банкноты и монеты Тувы как предмет нумизматики (по фондовым материалам Национального музея Республики Тыва) // Наследие народов Центральной Азии и сопредельных территорий: изучение, сохранение и использование. Материалы научно-практической конференции, г. Кызыл, 9-10 сентября 2009 г.: в 2-х ч. / сост. У. Б. Нурзат. Кызыл : КЦО «Аныяк». Ч. 1. 199 с. С. $18-26$.

Иезуитов, В. М. (1956) От Тувы феодальной к Туве социалистической. Кызыл : Тувинское книжное издательство. 208 с.

История Тувы (2007) : в 3 т. / под общ. ред. В. А. Ламина. Новосибирск : Наука. Т. II. 430 с.

Конституции Тувы (1999) : сборник к 55-летию принятия Тувы в состав СССР и РСФСР / сост. В. А. Дубровский. Кызыл : Тувинское книжное издательство. 216 с.

\footnotetext{
${ }^{1}$ Извещение исполнительного комитета областного Совета депутатов трудящихся Тувинской автономной области и Тувинского областного финансового отдела // Тувинская правда. 1945. № 41 от 7 апреля. С. 3.
} 
Копеел, В. А. (1981) Деньги и денежное обращение в период ТНР // По пути Великого Октября. К 60-летию Народной революции в Туве / отв. ред. Ю. Л. Аранчын. Кызыл : Тувинское книжное издательство. 156 с. С. 81-89.

Моллеров, Н. М. (1989) Истоки братства. Русская самоуправляющаяся трудовая колония в Тувинской Народной Республике. Кызыл : Тувинское книжное издательство. 144 с.

Тульчинский, Л. И. (1961) К вопросу о зарождении и развитии финасово-кредитной системы в Туве (1921-1944 гг.) // Ученые записки. Вып. IX. Кызыл : Типография управления культуры. С. 269-274.

Тульчинский, Л. И., Каплунов, А. И. (1972) Очерки бюджета Тувы / отв. ред. В. П. Солдатов. Кызыл : Тувинское книжное издательство. 136 с.

Харунова, М. М.-Б., Харунов, Р. Ш. (2019) Создание национальной денежной системы Тувинской Народной Республики (1921-1944 гг.) // Новые исследования Тувы. № 3. С. 208-221. DOI: https://doi.org/10.25178/nit.2019.3.17

Харунова, М. М.-Б., Харунов, Р. Ш., Санчай, Ч. О. (2019) Деньги Тувинской Народной Республики в коллекциях Национального музея Тувы // Новые исследования Тувы. № 2. C. 105-114. DOI: https://doi.org/10.25178/nit.2019.2.9

Экономика Тувинской АССР (1973) / отв. ред. С. В. Клопов. Кызыл : Тувинское книжное издательство. 380 с.

Дата поступления: 02.06.2020 г.

\section{REFERENCES}

Anan'in, A. Ia. and Rogov, G. I. (2014) Denezhnye znaki Tuvy [Banknotes of Tuva]. Antikvariat, predmety iskusstva $i$ kollektsionirovaniia, no. 9 (119), pp. 134-143. (In Russ.).

Aranchyn, Yu. L. (1982) Istoricheskii put' tuvinskogo naroda $k$ sotsializmu [The historical path of the Tuvan people to socialism]. Novosibirsk, Nauka. 337 p. (In Russ.).

Bicheldei, K. A. (2009) Denezhnaia reforma TNR 1925-1940 gg. - banknoty i monety Tuvy kak predmet numizmatiki (po fondovym materialam Natsional'nogo muzeia Respubliki Tyva). [The Money reform of the Tuvan People's Republic 1925-1944 - banknotes and coins of Tuva as a subject of numismatics (in the collections of The National Museum of the Republic of Tuva)]. In: Nasledie narodov Tsentral'noi Azii i sopredel'nykh territorii: izuchenie, sokhranenie i ispol'zovanie [A heritage of the people of Central Asia and adjacent territories: research, preservation and use] : Proceedings of the scientific and practical conference, Kyzyl, September 9-10, 2009: in 2 vol. / ed. by U. B. Nurzat. Kyzyl, KTSO «Anyiak». Vol 1. 199 p. P. 18-26. (In Russ).

Iezuitov, V. M. (1956) Ot Tuvy feodal'noi k Tuve sotsialisticheskoi [From feudal Tuva to socialist Tuva]. Kyzyl, Tuvan book publishing house. 208 p. (In Russ.).

Istoriia Tuvy [The History Of Tuva] (2007): in 3 vols. / ed. by V. A. Lamin. Novosibirsk, Nauka. Vol. 2. 430 p. (In Russ.).

Konstitutsii Tuvy [Constitutions of Tuva] (1999): a collection for the 55th anniversary of Tuva's accession to the USSR and RSFSR. Kyzyl, Tuvan book publishing house. 216 p. (In Russ.).

Kopeel, V. A. (1981) Den'gi i denezhnoe obrashchenie v period TNR [Money and monetary circulation during the TNR period]. In: Po puti Velikogo Oktiabria. K 60-letiiu Narodnoi revoliutsii v Tuve [On the way of the Great October. To the 60th anniversary of the people's revolution in Tuva] / ed. by Yu. L. Aranchyn. Kyzyl, Tuvan book publisher. 156 p. Pp. 81-89. (In Russ.).

Mollerov, N. M. (1989) Istoki bratstva. Russkaia samoupravliaiushchaiasia trudovaia koloniia v Tuvinskoi Narodnoi Respublike [The origins of the brotherhood. Russian self-governing labor colony in the Tuvan People's Republic]. Kyzyl, Tuvan book publishing house. 144 p. (In Russ.).

Tul'chinskii, L. I. (1961) K voprosu o zarozhdenii i razvitii finasovo-kreditnoi sistemy v Tuve (1921-1944 gg.) [On the origin and development of the financial and credit system in Tuva (1921-1944)]. Uchenye zapiski, Vol. IX. Kyzyl, Tipografiia upravleniia kul'tury. Pp. 269-274. (In Russ.).

Tul'chinskii, L. I. and Kaplunov, A. I. (1972) Ocherki biudzheta Tuvy [Essays on Tuva's budget]. Kyzyl, Tuvan book publishing house. 136 p. (In Russ.).

Kharunova, M. M.-B. and Kharunov, R. Sh. (2019) Sozdanie natsional'noi denezhnoi sistemy Tuvinskoi Narodnoi Respubliki (1921-1944 gg.) The rise of the national monetary system of the People's Republic of Tuva (1921-1944). New Research of Tuva, no. 3, pp. 208-221. (In Russ.). DOI: https://doi.org/10.25178/nit.2019.3.17 
Kharunova, M. M.-B., Kharunov, R. Sh. and Sanchai, Ch. O. (2019) Den'gi Tuvinskoi Narodnoi Respubliki v kollektsiiakh Natsional'nogo muzeia Tuvy Money of the People's Republic of Tuva in the collections of the Aldan-Maadyr National Museum of Tuva. New Research of Tuva, no. 2, pp. 105-114. (In Russ.). DOI: https://doi.org/10.25178/nit.2019.2.9

Ekonomika Tuvinskoi ASSR [The economy of Tuvan ASSR] (1973). Ed. by S. V. Klopov. Kyzyl, Tuvan book publishing house. 378 p. (In Russ.).

Submission date: 02.06.2020. 